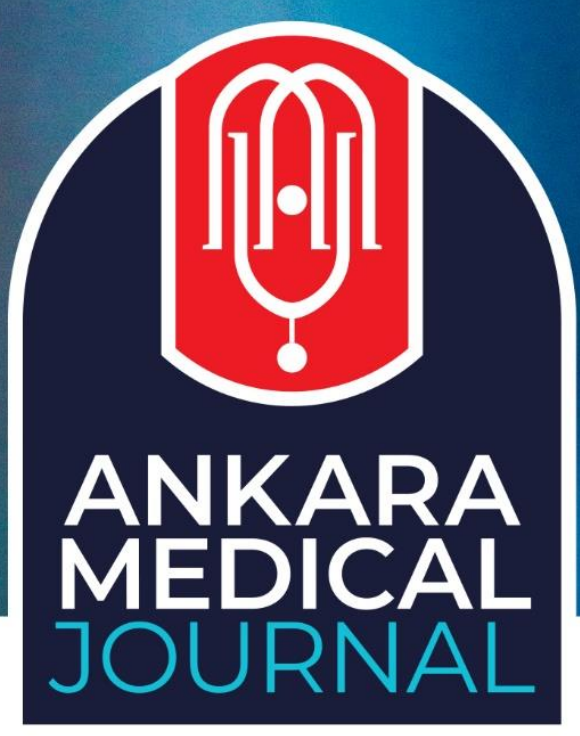

Review

Ankara Med J, 2020;(2):444-467 // (10) 10.5505/amj.2020.92679

\title{
COVID-19 IN PRIMARY HEALTHCARE
}

\section{BİRİNCI BASAMAKTA COVID-19}

(D) Hüseyin Acar1, (D) Yağmur Gökseven², (D) Güzin Zeren Öztürk ${ }^{3}$, (i) Seçil Arıca4

1 Ümraniye Zeyneloğlu Family Health Center, Istanbul, Turkey

${ }^{2}$ Hassa District Hospital, Hatay, Turkey

${ }^{3}$ University of Health Sciences, Şişli Hamidiye Etfal Education and Research Hospital, Family Medicine Clinics, Istanbul, Turkey

${ }^{4}$ University of Health Sciences, Prof. Dr. Cemil Taşçıŏlu City Hospital, Family Medicine Clinics, Istanbul, Turkey

Yazışma Adresi / Correspondence:

Hüseyin Acar (e-mail: hacar@windowslive.com)

Geliş Tarihi (Submitted): 26.04.2020 // Kabul Tarihi (Accepted): 04.05.2020

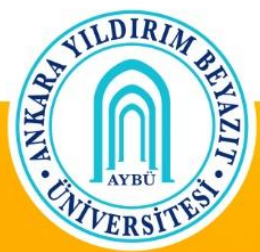

Ankara YIldırım Beyazıt University Faculty of Medicine Department of Family Medicine 


\title{
Öz
}

Koronavirüsler, hayvanları veya insanları enfekte edebilen ve Orta Doğu Solunum Sendromu (MERS) ve Şiddetli Akut Solunum Sendromu (SARS) gibi hastalıklara neden olan büyük bir virüs ailesidir. Yeni koronavirüs (SARS-CoV-2) Aralık 2019'da Wuhan şehrinde ortaya çıkan ve pnömoni, pulmoner ödem, ARDS, multiorgan yetmezliği ve ölüme sebebiyet verebilen bir solunum yolu enfeksiyon etkenidir. Tedavi çalışmaları devam etmekle birlikte şu an hidroksiklorokin, azitromisin, plazma tedavisi ve favipiravir gibi anti-viraller öne çıkan tedavilerdir. Hastalığın ölüm oranı \%3,8'dir. Yayılımın azalmasını sağlamak amacıyla yasal düzenlemeler yapılmıștır. Aile sağlığı merkezleri (ASM) çocuk, gebe, yaşlı, kronik hastalığı olan hastalar ve birtakım sağlık belgeleri için başvuran kişilere hizmet veren birinci basamak sağlık kurumlarıdır. Pandemi varlığında aile hekimleri, ASM'lere başvuran kişiler arasında virüs iletimini kısıtlamak zorundadır. Bu nedenle triaj yapılması yüksek riskli hastaları mümkün olan en kısa sürede saptamak için gereklidir. ASM'lere başvuran tüm hastalar bu şekilde korunabilir. Filyasyon yapıldıktan sonra, şüpheli vakalar veya COVID-19 ile temas eden vakalar aile hekimleri tarafından klinik durumlarının takip edilmesi ve izolasyon koșullarının kontrol edilmesi amacıyla günlük olarak takip edilmektedir. Tüm bu nedenlerden ötürü, COVID-19 ile mücadele eden aile sağlı̆̆ merkezlerini incelemeyi amaçladık.

Anahtar Kelimeler: COVID-19, SARS-CoV-2, pandemik, aile hekimliği, temel sağlık hizmeti.

\begin{abstract}
The coronaviruses are a large family of viruses infecting animals or humans and causing diseases, including Middle East Respiratory Syndrome(MERS, MERS-CoV) and Severe Acute Respiratory Syndrome(SARS, SARSCoV). The novel coronavirus SARS-CoV-2 emerged in December 2019 at the city of Wuhan, affecting the respiratory system leading to pneumonia, pulmonary edema, Acute Respiratory Distress Syndrome, multiorgan failure, and death. Treatment studies are still ongoing, but hydroxychloroquine, azithromycin, oseltamivir, favipiravir with some other anti-virals, and convalescent plasma therapy are prominent. The mortality rate of disease is $3.8 \%$ in the world, infesting many countries. Legal regulations have been made for the public to reduce transmission. Family health centers are providing healthcare services to every individual, for example, children, pregnant, patients with chronic diseases, patients with any complaint, and individuals who applied for health papers. In such a pandemic family, physicians also have to restrain the transmission of viruses between those people who applied. Therefore triage is needed to determine the high-risk patients as soon as possible. Both of them and other patients are protected in that way. After the filiation is done, suspected cases or COVID-19 contacted cases are kept in touch by family physicians to follow up their clinical status and check for isolation conditions. For all these reasons, we aimed to examine the family health centers coping with COVID-19.

Keywords: COVID-19, SARS-CoV-2, pandemics, family practice, primary health care.
\end{abstract}




\section{Introduction}

The coronaviruses are a large family of viruses infecting animals or humans and causing diseases, including Middle East Respiratory Syndrome(MERS, MERS-CoV) and Severe Acute Respiratory Syndrome(SARS, SARS$\mathrm{CoV}$ ). SARS, as a viral respiratory tract infection, infected more than 8000 people in 37 countries and caused death of 774 people, in 2002. Mortality rate was $9.6 \%$ and was isolated on the Himalayan masked palm civets. Turkey, had not reported any SARS case..$^{1,2}$

MERS is also a respiratory tract infection which was detected in Saudi Arabia , in 2012 and to day infected 2519 people in 27 countries and causing death of 866 people. Mortality rate is $34.3 \%$. Humans are thought to be infected by dromedary camels and human-to-human transmission is very rare except for close contact. ${ }^{3}$

Third zoonotic human coronavirus disease of 21th century emerged in December,2019, city of Wuhan. There were a group of pneumonia cases of unknown cause and were somehow related to the Huanan seafood market. ${ }^{4}$ In January, 2020, that virus is named shortly SARS-CoV-2, which is enveloped, positive-sense, single stranded RNA viruses. The disease caused was named COVID-19. 5,6

\section{Transmission}

Coronaviruses causes diseases on humans by spreading from animals. Avians, camels, bats, mice, dogs, masked palm civets and cats are hosts. But many coronavirus types don't cause illness on humans. Transmission is mainly by droplets and indirect contact. ${ }^{7}$

Droplets: Droplets are small particles larger than size of $5 \mu \mathrm{m}$. They can't stay in the air for long periods and can't spread to wide range of areas. Aerosols are smaller than size of $5 \mu \mathrm{m}$ particles containing virus. Droplets spread from hosts by coughing, sneezing, talking, laughter and aerosols spread by medical procedures like, bronchoscopy, intubation or aspiration can reach 1-2 meters ; can infect conjunctiva, oral and nasal mucosa. SARS-CoV-2 viruses can survive up to 3 hours in an aerosol with a half-life of 1.1-1.2 hours. ${ }^{8}$

Indirect contact: That means carrying the infecting agent with an intermediate object or a fomite. In that way of contamination, secretions from respiratory tract of diseased person contact with the susceptible host's hand and host can touch conjunctiva, oral and nasal mucosa with them.

SARS-CoV-2 viruses can survive:

-On copper up to 4 hours (median half-life of 1.1-1.2 hours ) 
-On cardboard up to 24 hour (median half-life of 3.5 hours )

-On stainless steel up to 2 days (median half-life of 5.6 hours )

-On plastic up to 3 days (median half-life of 6.8 hours ). ${ }^{8}$

Incubation period of SARS-CoV-2 changes from 2 to 14 days with a mean of 5-6 days. ${ }^{6}$ Secondary attack rate varies in different populations 1 to $5 \% .{ }^{9}$ In a research conducted in U.S. , 10 COVID-19 patients and their 445 close contacts were evaluated and secondary attack rate was found to be $0.45 \% .{ }^{10}$

Contamination from asymptomatic people or from in the incubation period is described however it's not very well known to what extent it occurs. In a research in Singapore, secondary attack rate from asymptomatic people is stated $6.4 \% .11$

SARS-CoV-2 also seen in stool samples in the report published by China and WHO, but this was stated not to be important in transmission of COVID-19.9

\section{Symptoms and Signs}

Coronavirus generally causes respiratory tract infections in humans. The disease causes $81 \%$ asymptomatic or mild, 14\% serious and 5\% critical illness. Pneumonia, pulmonary edema, Acute Respiratory Distress Syndrome(ARDS), multiorgan failure and death may occur. Although symptoms generally manifest with fever, dry cough, dyspnea, there are case studies in the literature showing various complaints like headache, nasal congestion, sore throat, muscle and joint pain, weakness, nausea / vomiting and diarrhea may occur (Table 1). ${ }^{12-16}$ Pneumonia is the primary cause(91\%) of hospitalization. ${ }^{16}$

\section{Diagnosis}

\section{Laboratory Tests}

Blood samples: Blood tests are not diagnostic. Mostly lymphopenia and leukopenia are seen. In a metaanalysis, Laboratory findings were leukocytosis in 11\%, leukopenia in 36.9\%, lymphopenia in 57.4\%, elevated C-reactive protein (CRP) in 61.3\%, elevated lactate dehydrogenase (LDH) in 57\% of results. In some patients, increased liver function tests, creatinine kinase, D-dimer values were observed. ${ }^{17}$ 
Table 1. Distribution of Symptoms for COVID-19 in Literature

\begin{tabular}{|l|c|c|c|c|c|}
\hline & $\begin{array}{c}\text { Wang C. et al. } \\
\mathrm{n} \mathrm{( \% )}\end{array}$ & $\begin{array}{c}\text { Chen N. et al. } \\
\mathrm{n}(\%)\end{array}$ & $\begin{array}{c}\text { Wang D. et al. } \\
\mathrm{n}(\%)\end{array}$ & $\begin{array}{c}\text { Tian S. et al. } \\
\mathrm{n}(\%)\end{array}$ & $\begin{array}{c}\text { Guan et al. } \\
\mathrm{n}(\%)\end{array}$ \\
\hline Fever $\left(\geq 38^{\circ} \mathrm{C}\right)$ & $40(98)$ & $82(83)$ & $136(98.6)$ & $105(40)$ & $235(21.7)$ \\
\hline Cough & $31(76)$ & $81(82)$ & $82(59.4)$ & $120(45.8)$ & $745(67.8)$ \\
\hline Dyspnea & $22(55)$ & $31(31)$ & $43(31.2)$ & $18(6.9)$ & $205(18.7)$ \\
\hline Muscle pain & - & $11(11)$ & $48(34.8)$ & - & $164(14.9)$ \\
\hline Confusion & - & $9(9)$ & - & - & - \\
\hline Headache & - & $8(8)$ & $9(6.5)$ & $17(6.5)$ & $150(13.6)$ \\
\hline Sore throat & - & $5(5)$ & $24(17.4)$ & - & $153(13.9)$ \\
\hline $\begin{array}{l}\text { Nasal } \\
\text { congestion }\end{array}$ & - & $4(4)$ & - & - & $53(4.3)$ \\
\hline Chest pain & - & $2(2)$ & - & - & - \\
\hline Diarrhea & $1(3)$ & $2(2)$ & $14(10.1)$ & - & $42(3.8)$ \\
\hline $\begin{array}{l}\text { Nausea and } \\
\text { Vomiting }\end{array}$ & - & $1(1)$ & $5(5.6)$ nausea & & $55(5)$ \\
\hline Weakness & - & - & $96(69.6)$ & $69(26.3)$ & $419(38.1)$ \\
\hline Total Case & $41(100)$ & $99(100)$ & $138(100)$ & $262(100)$ & $1099(100)$ \\
\hline
\end{tabular}

Real Time Polymerase Chain Reaction (RT-PCR): That methods is used to determine the virus presence on respiratory secretions and first choice of testing for diagnosis. In a 205 patient study, 1070 specimens collected from them showed positive rates of $93 \%$ in bronchoalveolar lavage fluid, $72 \%$ in sputum, $63 \%$ in nasal swabs, $46 \%$ in fibro bronchoscope brush biopsies, $32 \%$ in pharyngeal swabs and $29 \%$ in feces. ${ }^{18}$ RT-PCR may give false negative results. While its sensitivity on first 7 days of disease is $67 \%$, after 15 th day decreases to $45 \% .{ }^{19}$ When sampling from the upper respiratory tract, from the oropharynx and then the nasopharynx the same swab must be used and sent to lab in the same medium. Yet, the difficulties or problems with the sampling and transfer may affect the result. ${ }^{20}$

Serological testing: Viral serological tests are effective methods in SARS-CoV-2 diagnosis. After 15th day, IgM and IgG antibodies show sensitivity of 94\% and 80\% in COVID-19.19 Evaluating IgM, IgG and RT-PCR together can provide information about the infection period. 
-RT-PCR (+), IgM (-), IgG (-); window period,

-RT-PCR (+), IgM (+), IgG (-); early periods of the infection,

-RT-PCR (+), IgM (-), IgG (+); late period of the infection or recurring,

-RT-PCR (-), IgM (-), IgG (+); infected and cured,

-RT-PCR (-), IgM (+), IgG (-); window period,

-RT-PCR (-), IgM (+), IgG (+); cure period or RT-PCR false negative. ${ }^{21}$

\section{Radiological Studies}

Postero-anterior Chest X-ray: The sensitivity of Chest X-ray is 30-60\%.22 At early stages of disease images can be found normal and that doesn't exclude pneumonia. Especially children and young adults Chest X-ray should be first choice of imaging.

Computerized Tomography(CT): Characteristic chest CT findings are widespread peripheral and bilateral involvement mostly starting from the middle-lower zones, ground glass opacities, consolidations, crazy-paving appearance, air bronchogram, vascular dilation and bronchial changes. ${ }^{23}$ In a retrospective study conducted with 1,014 patients in China, the accuracy of CT was 97\%, specificity 25\% and accuracy in detecting COVID-19 as $68 \%$; positive predictive and negative predictive values were $65 \%$ and $83 \%$, respectively. ${ }^{24}$

Based on whole data, it is concluded that the evaluation by RT-PCR alone may be insufficient for the diagnosis of COVID-19.

\section{Treatment}

Since SARS-CoV-2 is a newly identified virus, there is no effective antiviral treatment yet. The main treatment is symptomatic, but in many studies, antiviral drugs such as oseltamivir, ribavirin, ganciclovir, remdesivir, lopinavir and ritonavir have been used to reduce viral load and prevent a possible respiratory complication. 4,6,13,14 However, randomized controlled trials are needed to confirm the effectiveness of all these antiviral drugs in COVID-19 treatment.

Chloroquine (CQ) is commonly used as an antimalarial, hydroxychloroquine (HCQ) is widely used in autoimmune diseases such as lupus, rheumatoid arthritis. Antiviral efficacy has been demonstrated by in vitro studies in the late 1960s. ${ }^{25}$ Later in 2000s, both CQ and HCQ were found to have antiviral activity on many 
viruses such as SARS, MERS, Ebola in cell cultures. ${ }^{26}$ Recent studies have shown that CQ or HCQ SARS-CoV-2 are effective in controlling infection, and CQ prevents exacerbation of pneumonia, improves radiological findings in the lung, shortens the course of the disease and prevents viral spread in the postinfectious period. ${ }^{27,28}$ HCQ comes forward because it is safer than CQ. ${ }^{29}$

In a study, it was stated that HCQ and azithromycin had a synergistic effect and in the patient group using this combination, there was a significant decrease in viral load and viral transmission times compared to the control groups on the sixth day of treatment. Both HCQ and azithromycin prolong the QT interval. In a review, patients using HCQ were evaluated based on the development of toxicity, and it was found later on that $85 \%$ of them had conduction disorders, 26.8\% heart failure, 22\% ventricular hypertrophy, and 9.4\% hypokinesia. ${ }^{30}$ Therefore it is recommended to record the QRS duration, PR and corrected QT intervals of patients with 12lead ECG before starting treatment in patients planning combination therapy with HCQ. In the patient who has already started treatment, it is recommended to make that examination approximately 3 hours after the second dose of HCQ loading dose on the first day of treatment. ${ }^{31}$ It is recommended that patients who have risk factors like, advanced age, cardiac comorbidity, electrolyte disturbance, or use other drugs that prolong QT duration should be evaluated for risk and should be consulted to cardiology if necessary. ${ }^{20}$

The treatments currently applied in our country according to disease' stage are given in Figure 1 and Figure $2 .{ }^{20}$ However, as experience on COVID-19 increases updates and changes are made in treatment and application forms. These figures are prepared according to the 14.04 .2020 dated guide.

Patients whose clinical status or pneumonia findings worsen while taking HCQ treatment may be considered to start favipiravir treatment at the doses indicated in Figure 2, and HCQ treatment should be completed to 10 days.

In uncomplicated possible or diagnosed COVID-19 pregnant cases, first step in therapy is follow-up without drug treatment. However, drugs should be considered in the presence of risk factor or clinical deterioration (Figure 3). ${ }^{20}$

\section{Promising Drugs for COVID-19 Treatment}

Lopinavir and ritonavir are protease inhibitors used in HIV treatment. Antiviral activities have been reported for MERS and SARS viruses, but their efficacy in SARS-CoV-2 therapy is controversial. 


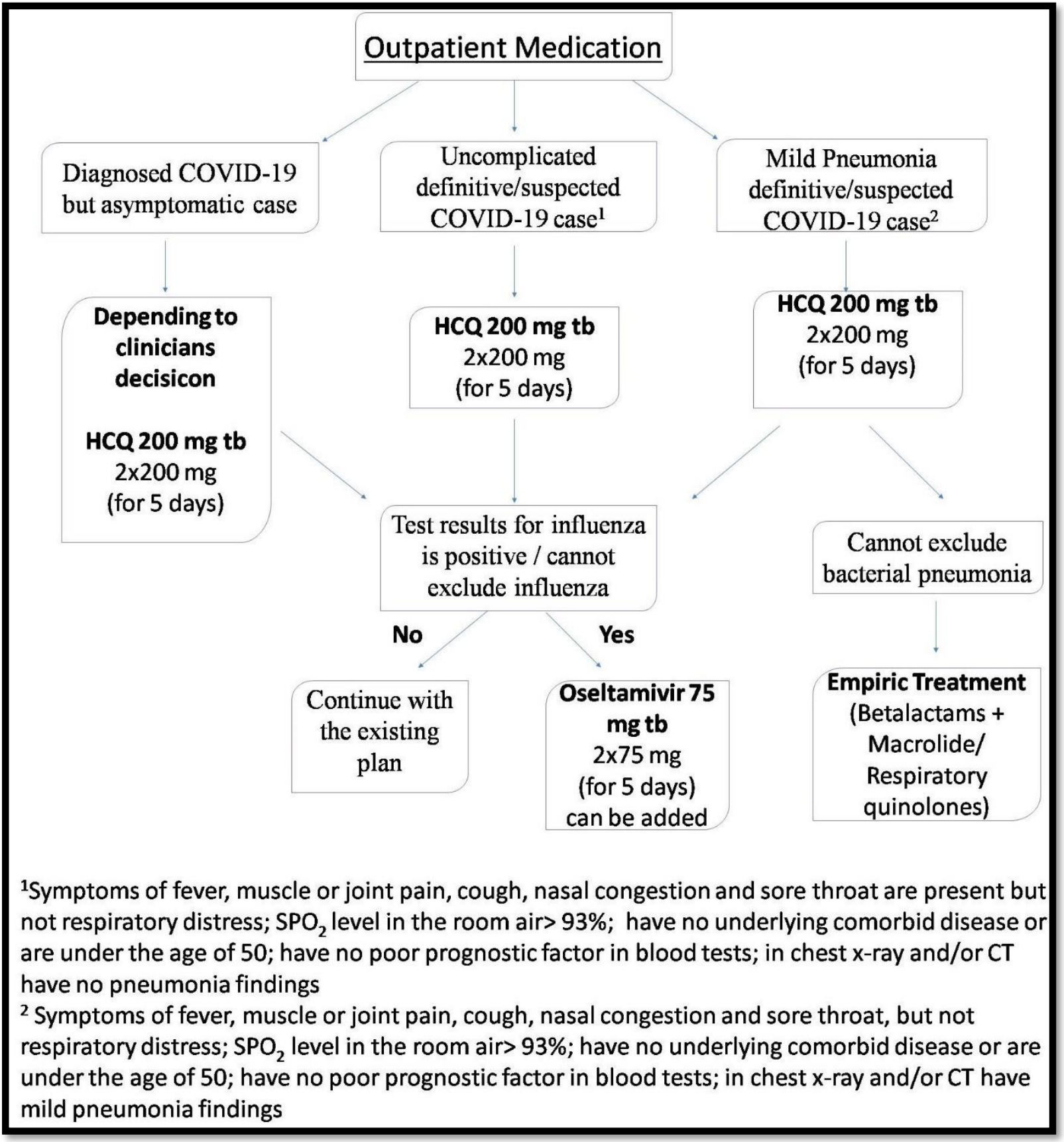

Figure1. Treatment plan suggested for diagnosed/suspected COVID-19 Patients to be followed as outpatient 


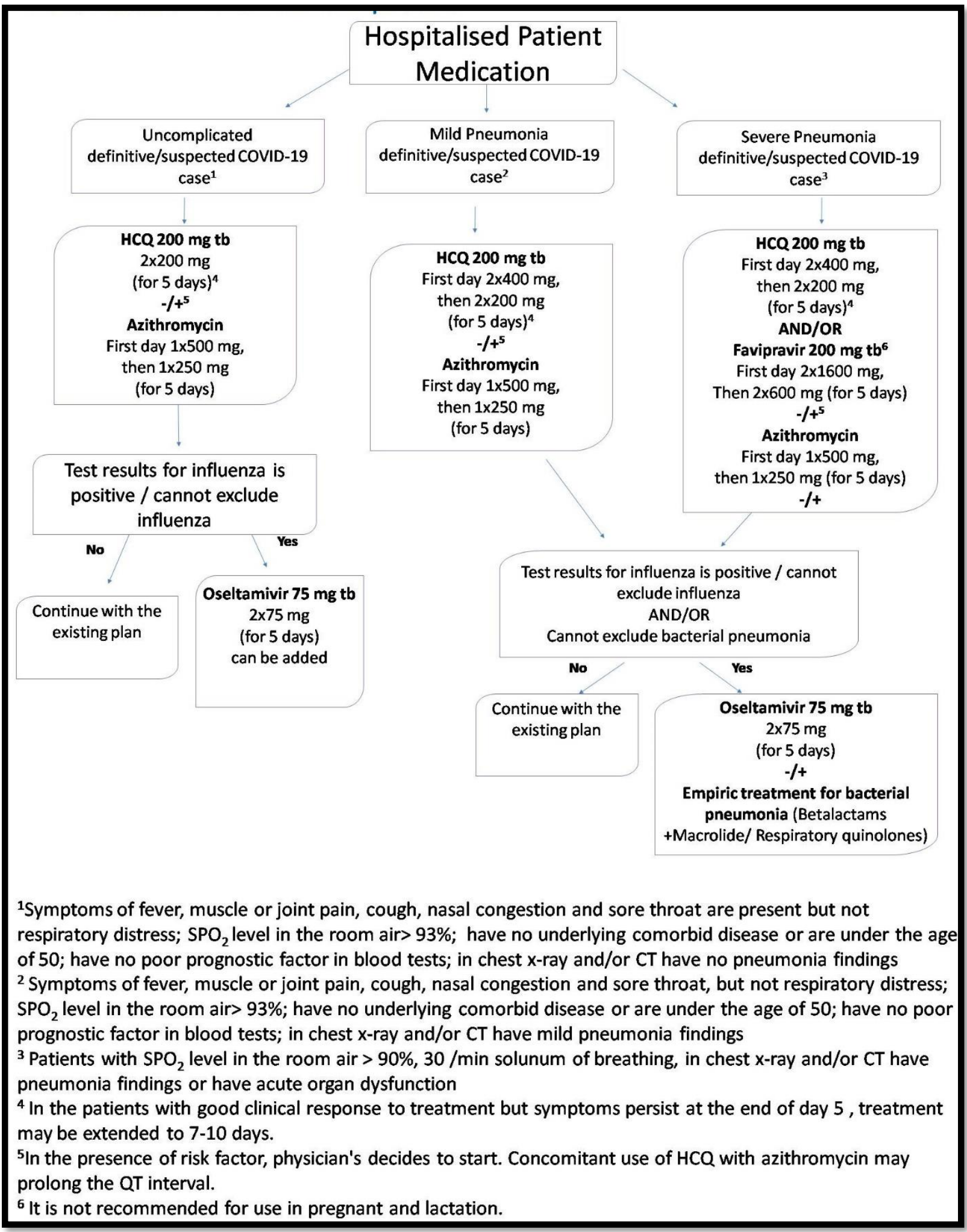

Figure 2. Treatment plan suggested for diagnosed/suspected COVID-19 Patients to be followed as inpatient 
Ribavirin is a nucleotide analogue used in the treatment of Hepatitis C virus, Respiratory Syncytial Virus, SARS and MERS viruses. There is no clear evidence on its efficacy and safety, and it can cause anemia at high doses. ${ }^{26}$

Favipiravir is a guanine analogue used in the treatment of infections such as influenza, Ebola, yellow fever, norovirus and enterovirus related diseases. Recent studies have shown that the virus has antiviral effects in Vero E6 cells and can be therapeutic for COVID-19.27

Remdesivir is an adenosine analogue. It showed antiviral activity for MERS-CoV and SARS-CoV in the human respiratory epithelium and inhibited MERS-CoV replication in mice. It was firstly developed and used for Ebola treatment. It is one of the promising treatment candidates for SARS-CoV-2. However, clinical studies are needed to confirm therapeutic activity and safety of both favipiravir and remdesivir. ${ }^{26}$

Convalescent plasma therapy is a passive immunity method that is given to the susceptible person by delivering antibodies collected from people who have previously been infected with the virus. Its effects have seen in recent years against many viral pathogens, including MERS and SARS viruses. It is a promising treatment, but its safety and efficacy for COVID-19 has not been demonstrated yet. ${ }^{32}$

Darunavir, imatinib, interferon alpha, teicoplanin and many more drugs are considered to be potential drugs for the treatment of COVID-19, but there is no effective and safe drug specific to virus yet. ${ }^{33}$

\section{Pregnants with any risk factor or severe clinical status.}

Lopinavir $200 \mathrm{mg} /$ ritonavir $50 \mathrm{mg}$ tb

$2 \times 2$

(for 10-14 days)

OR

HCQ $200 \mathrm{mg}$ tb

$2 \times 200 \mathrm{mg}$,

(for 5 days)

Figure 3. Treatment plan for pregnant 


\section{Prognosis}

The mortality of COVID-19 is 3.8\%(20) In our country, mortality rate is $2.1 \%$ and these are lower than SARS and MERS. In the presence of severe ARDS, approximately 50\% of patients have a mortal clinical course. However, male gender, advanced age $(\geq 64)$, presence of comorbidities (hypertension, diabetes, cancer, chronic heart, lung or kidney diseases), severe lymphopenia $(<800 / \mu \mathrm{l})$, elevated liver function tests, LDH, CRP $(>40$ $\mathrm{mg} / \mathrm{l}$ ), ferritin ( $>500 \mathrm{ng} / \mathrm{ml}$ ), D-dimer (>1000ng/ml), kidney function tests and increased prothrombin time are poor prognostic factors. ${ }^{34}$

In the study by Miller A. et al., It was found that the countries which started BCG vaccination in earlier years or countries where BCG vaccine has been administered for longer years have a lower mortality rate associated with COVID-19 per million population. ${ }^{35}$

\section{Infectivity after treatment}

After the COVID-19 treatment, in the patient who had no symptoms and had two negative oropharynx RT-PCR result taken 24 hours apart, it was found to be positive result on third day. The infectious period of COVID-19 disease is not yet fully known. People in the recovery period may also be contagious. Therefore, it is recommended that quarantine be continued for 14 days after therapy. ${ }^{36}$

\section{Prevention}

\section{Chemoprophylaxis}

It is thought CQ (and possibly HCQ by the similar mechanism) to inhibit SARS-CoV-2 spread before and after infection, so can be used for both prophylactic and therapeutic purposes for COVID-19.37 It is not yet recommended by the $\mathrm{CDC}$ due to the lack of randomized controlled trials on its dosing and duration. ${ }^{38}$ However, the Medical Research Council of India provides HCQ to all healthcare workers who were in contact with suspected / definitive COVID-19 cases, uses oral on the first day $400 \mathrm{mg} 2 \times 1$, then $400 \mathrm{mg}$ once a week for seven weeks. They also recommends the oral use of $400 \mathrm{mg} 2 \times 1$ for first day then $400 \mathrm{mg}$ once a week for three weeks to asymptomatic household who were in contact with a diagnosed COVID-19 patient. ${ }^{39}$

\section{Vaccination}

Globally, there are about 15 potential vaccine candidates with developed technologies and techniques, but It is estimated to take more than a year for most of them to begin phase 1 clinical trials. Safety and immunogenetic clinical trials are taking place with 45 volunteers on an RNA vaccine (mRNA-1273) developed in the United 
States. Another vaccine candidate developed in China is the recombinant adenovirus vaccine (Ad5-nCoV) and phase 1 clinical trials continue with 108 healthy people. ${ }^{38}$

A possible secondary influenza or bacterial infection added to COVID-19 may increase the risk of morbidity and mortality. Therefore, in line with WHO recommendation, regardless of COVID-19 pandemic, it is highly recommended to apply vaccines, which are protective against respiratory infections such as influenza and pneumococcal diseases. ${ }^{40}$

\section{Advice for the Public}

People with COVID-19 suspect or diagnosis must isolate themselves from the community for 14 days. In case of any need of contact, they should definitely use a medical mask and there should be at least 1-meter distance between each person around. At home, if possible, the sick person should have a separate bathroom and bedroom. If it is not possible, it is necessary to use a medical mask, to maintain the social distance and to frequently ventilate the room while sharing the same room with other people.

It is recommended to use a medical mask in case the people who care for the patient enters the patient's room, to use gloves and apron besides the mask in cases that require direct contact with the patient or the patient's waste. Although WHO does not recommend the use of personal protective equipment in public areas in the community without any symptoms, in our country in the circular issued by the Ministry of the Interior on 03.04.2020, citizens and employees were required to wear masks at market places, markets, crowded covered all work places. It is stated that citizens will not be allowed to go out on the streets regardless of their social distance. ${ }^{41,42}$ Mask policies became the subject of controversy worldwide. However, after the asymptomatic transmission is partially understood, it is very important for every individual to wear mask especially when getting in contact with other people. ${ }^{43}$

\section{Risk and Case Management in Primary Care}

Family Health Centers are centers with multiple service offerings in primary health care. On the one hand, they provide outpatient clinic services to patients from all ages, complaints or diseases and on the other hand, provide protective services to healthy individuals. For this reason, triage and daily work plan in the family health center are crucial for preventing contamination.

At this point, triage is needed to identify the risky patient, if possible, before entering the building of the family health center. The Ministry of Health's "Possible COVID-19 Case Inquiry Form" should be used. Three important symptoms that should be asked to the patient in triage are fever or recent presence, cough and difficulty in breathing. If they are not present, the questions are asked whether he / she or someone from the household 
came from abroad in the last 14 days, hospitalization related to the respiratory tract problem in the last 14 days of someone known, or a diagnosis of COVID-19. Any confirmatory answer to these questions makes the patient at the high-risk category of possible COVID-19, at first sight. The individual at high risk should be further assessed in a separate pre-prepared room. ${ }^{20}$

The examination of patients with low risk can be continued according to normal outpatient clinic conditions, but it should not be forgotten that; asymptomatic contamination is a critical condition for COVID-19. In addition, a different examination finding, complaint or clinic history that may be overlooked in the triage evaluation may yield risky results in the patient. For all these reasons, it is recommended that almost every examination at the family health center be carried out with great care and protective equipment support.

The algorithm in Figure 4 can be used in terms of how people who apply to family health center are directed according to their complaints, reasons to apply and clinical risk situations. ${ }^{20,42,44,45}$

\section{Exposure of Healthcare Workers, Personal Protective Equipment}

\section{Area for Triage and COVID-19}

The area to be used for triage should be located near the entrance of the family health center. Proper conditions to measure temperature with non-contact thermometers and enough space to keep 1-meter distance with ne patient needed. The minimum item must exist in that area or room. Likewise, in the prepared room reserved for COVID-19, the items should be minimized and the examination table and equipment conditions required for the consultation should not be missing. It is important that unnecessary entrance and exit to the room must be limited and the materials cannot be changed place continuously. Single use products should be selected if possible on equipment and table covers.

\section{Advice for Cleaning}

It is shown in Table 2 some practical advice for cleaning the areas, fixture and equipments. ${ }^{20,46,47}$

\section{Personal Protective Equipment}

Among the personal protective equipment (PPE), medical masks, gloves and coveralls should be disposable.

Medical mask is water resistant. It protects wearer against large droplets, body fluids, splashes and flushes of fluids. However, it does not reliably protect from small airborne particles and is not considered respiratory protective. Latter should be discarded when wet, moist or after each patient. It must be disposable. 


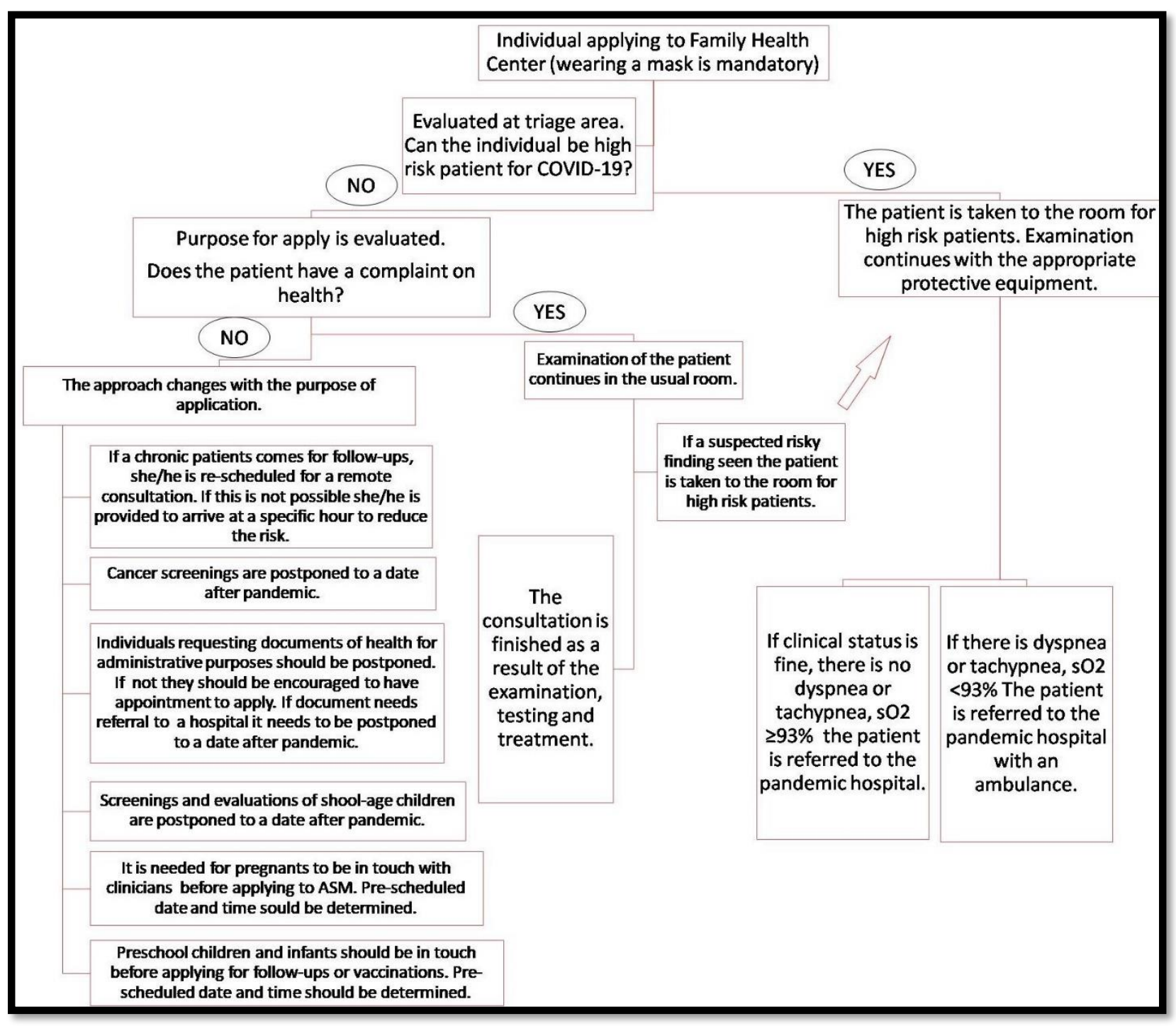

Figure 4. Algorithm for patients applying to family health center

N95 is the air filtration standard used in the United States. This refers to how much of the standard mask can filter particles of size 0.3 microns. N95 masks which also can be named respirators, protect users against small particles of aerosols and large droplets. They filter 95\% of large and small particles. Accordingly, N95 masks have the capacity to filter $95 \%$ of particles, 97\% of N97 masks and 99.97\% of N100 masks. FFP masks are the European version of the N95 classification. FFP1 masks have the capacity to filter 80\%, FFP2 masks 94\% and FFP3 masks can filter $99.95 \%$ of the particles according to the 0.3 micron particle filtering capacity. ${ }^{48}$

The mask should be placed on the face properly. It should be discarded when damaged, got wet, contaminated with body fluids. As a suggestion in the guides, the replacement of the N95 mask is recommended in every risk patient. ${ }^{49}$ However, a worldwide pandemic may diminish any equipment. If there is no possibility to change in 
that frequency, during the evaluation of high-risk patients, wearing a medical mask in front of the N95 mask and changing the medical mask after that patient may be an option for difficult times.

Table 2. Some practical recommendations for cleaning the family health center

\begin{tabular}{|c|c|c|}
\hline & Disinfecting agent & Recommendations \\
\hline Areas for COVID-19 & & $\begin{array}{l}\text { It should not be forgotten to ventilate the } \\
\text { room after the patient. Then cleaning } \\
\text { starts. }\end{array}$ \\
\hline $\begin{array}{l}\text { Surface cleaning and } \\
\text { surfaces where body } \\
\text { fluids can scatter }\end{array}$ & $\begin{array}{l}\text { Standard Bleach-Sodium } \\
\text { hypochlorite (1:10 dilution) }\end{array}$ & \multirow{2}{*}{$\begin{array}{l}\text { All surfaces and outer parts of items are } \\
\text { wiped off after the high risk patient. } \\
\text { Cleaning starts from the highest or the } \\
\text { hardest to reach area. Organic materials } \\
\text { should be swept first. If possible, the } \\
\text { cleaning cloths must be disposable. }\end{array}$} \\
\hline Floor cleaning & $\begin{array}{l}\text { Standard Bleach-Sodium } \\
\text { hypochlorite (1:10 dilution) or } \\
\text { Accelerated Hydrogen Peroxide } \\
0.5 \%\end{array}$ & \\
\hline \multicolumn{3}{|l|}{$\begin{array}{l}\text { All other surfaces and } \\
\text { floors }\end{array}$} \\
\hline Surface cleaning & $\begin{array}{l}\text { Standard Bleach-Sodium } \\
\text { hypochlorite (1:100 dilution) }\end{array}$ & $\begin{array}{l}\text { Seats in the waiting area should not be } \\
\text { forgotten. It should be cleaned twice a day. }\end{array}$ \\
\hline Floor cleaning & $\begin{array}{l}\text { Standard Bleach-Sodium } \\
\text { hypochlorite (1:100 dilution) or } \\
\text { Accelerated Hydrogen Peroxide } \\
0.5 \%\end{array}$ & It should be cleaned twice a day. \\
\hline Examination room & & $\begin{array}{l}\text { All items should be minimized in the } \\
\text { examination room and physician's desks. }\end{array}$ \\
\hline Examination tables & $\begin{array}{l}\text { Standard Bleach-Sodium } \\
\text { hypochlorite (1:100 dilution) }\end{array}$ & Coverings should be disposable \\
\hline $\begin{array}{l}\text { Stethoscope, otoscope, } \\
\text { pulse oximetry devices } \\
\text { and other needed } \\
\text { materials }\end{array}$ & $\begin{array}{l}\text { Alcohol Solutions (Ethyl / isopropyl) } \\
\text { (at least 70\%) }\end{array}$ & $\begin{array}{l}\text { Disinfection should be provided after each } \\
\text { patient. }\end{array}$ \\
\hline $\begin{array}{l}\text { Physicians' desk, } \\
\text { computer and other } \\
\text { stuffs. }\end{array}$ & $\begin{array}{l}\text { Alcohol Solutions (Ethyl / isopropyl) } \\
\text { (at least 70\%) }\end{array}$ & $\begin{array}{l}\text { It should be disinfected at least twice a } \\
\text { day. }\end{array}$ \\
\hline $\begin{array}{l}\text { Lunch and resting } \\
\text { rooms }\end{array}$ & $\begin{array}{l}\text { Standard Bleach-Sodium } \\
\text { hypochlorite (1:100 dilution) or } \\
\text { Accelerated Hydrogen Peroxide } \\
0.5 \%\end{array}$ & $\begin{array}{l}\text { Surfaces of tables, chairs, stands etc. } \\
\text { should be cleaned according to the } \\
\text { frequency of use. Rooms should never use } \\
\text { more than the capacity, should be } \\
\text { ventilated well. }\end{array}$ \\
\hline $\begin{array}{l}\text { Common use areas } \\
\text { Door handles, queuing } \\
\text { machines, electric } \\
\text { buttons etc. }\end{array}$ & $\begin{array}{l}\text { Standard Bleach-Sodium } \\
\text { hypochlorite (1:100 dilution) }\end{array}$ & $\begin{array}{l}\text { It is important to clean frequently all } \\
\text { surfaces with contact risk. }\end{array}$ \\
\hline
\end{tabular}


In studies with N95 masks for re-use of personal protective equipment, ultraviolet (UV) rays have been found to reduce the amount of bacteria on N95 masks. Although similar results have been obtained for coronaviruses, comparative studies have not been conducted for SARS-CoV-2 yet. ${ }^{50}$

It is determined as an effective method for disinfection of N95 mask by hanging it with a plastic clip without touching the metal surfaces in the oven for 30 minutes at $70^{\circ} \mathrm{C}$. There are more than one suggestion for steam disinfection. It has been emphasized that exposure of boiling water to steam for 10 minutes or $125^{\circ} \mathrm{C}$ steam for 3 minutes is effective methods for N95 mask disinfection. ${ }^{50,51}$

The filtration surfaces of N95 masks are made of a hydrophobic plastic material and can dry in about 2-3 days in dry environment. For this reason, four N95 masks can be can be used in order by numbering (3 days to dry 1 day use). ${ }^{50}$ Goggles, face shields, apron and N95 masks are re-usable equipment. Detailed information on cleaning them is given in Table 3.

Table 3. Disinfection recommendations for reusable personal protective equipment

\begin{tabular}{|l|l|}
\hline Personal Protective Equipment & Disinfection methods \\
\hline Aprons & $60-90^{\circ} \mathrm{C}$, with detergent \\
\hline N95 masks & $\begin{array}{l}\text { 1) Boiling water vapor (10 minutes) } \\
\text { 2) At oven } 70^{\circ} \mathrm{C}(30 \text { minutes) } \\
\text { 3) UV application * (254 nm, 8W, } 30 \text { minutes) } \\
\text { 4) It can be used alternately for } 1 \text { day use and drying outdoors } \\
\text { for } 3 \text { days. }\end{array}$ \\
\hline Goggles / face shields & $\begin{array}{l}\text { They should be cleaned according to the manufacturer's } \\
\text { recommendation. If there is no recommendation, it should be } \\
\text { disinfected with } 70 \% \text { ethyl alcohol and allowed to dry. }\end{array}$ \\
\hline
\end{tabular}

\section{Healthcare Workers}

Healthcare workers are the riskiest group for COVID-19 infection. According to the Turkish Medical Association report, COVID-19 infection is considered as a work accident in healthcare workers. So, incidents related to COVID-19 should be reported as work accidents. For example, when a health professional or a person working in health services (safety, attendant, driver, secretary, etc.) has a splash or contamination of the patient's cough, 
sneeze and other body fluids in the respiratory tract, or open wounds, it is necessary to report this as a work accident. Although there is no clear evidence of a sudden incident, if a health worker or healthcare professional is diagnosed with COVID-19, a notification of occupational disease should be made, taking into account the close link of the disease to the work done. Covid-19 diagnosis is a work accident or occupational disease..$^{52}$

It is shown below Table 4 the personnel protective equipment(PPE) of healthcare workers for situations to be encountered. 20,53

The order in which PPE is worn and removed is very important in terms of contamination. It is shown in the Figure 5.54

Table 4. Personnel protective equipment for different conditions at family health center

\begin{tabular}{|c|c|c|c|c|c|}
\hline & $\begin{array}{c}\text { Medical } \\
\text { mask }\end{array}$ & $\begin{array}{l}\text { N95 } \\
\text { mask }\end{array}$ & $\begin{array}{l}\text { Goggles } \\
\text { or } \\
\text { Face } \\
\text { shield } \\
\end{array}$ & Gloves & Apron \\
\hline \multicolumn{6}{|l|}{ TRIAGE - Family physician or medical staff } \\
\hline \multicolumn{6}{|l|}{$\begin{array}{l}\text { EXAMINATION AND OTHER PROCEDURES } \\
\text { AT COVID-19 AREA - Family physician }\end{array}$} \\
\hline \multicolumn{6}{|l|}{$\begin{array}{l}\text { LOW RISK PATIENT EXAMINATION - Family } \\
\text { physician * }\end{array}$} \\
\hline \multicolumn{6}{|l|}{$\begin{array}{l}\text { ALL MEDICAL INTERVENTIONS WITH CLOSE } \\
\text { CONTACT - Family physician** or medical } \\
\text { staff** }\end{array}$} \\
\hline \multicolumn{6}{|l|}{ DURING OTHER WORKS } \\
\hline \multicolumn{6}{|l|}{ Cleaning staff*** } \\
\hline \multicolumn{6}{|l|}{ Medical secretary } \\
\hline \multicolumn{6}{|c|}{$\begin{array}{l}\text { * In the case of an oropharynx examination, eyeglass or face protection may be appropriate. } \\
\text { ** Glasses or face shield should be used under conditions where droplets may occur. } \\
\text { *** Glasses or face shield should also be used in conditions where organic chemicals may splash. Closed } \\
\text { shoes should be preferred. }\end{array}$} \\
\hline
\end{tabular}




\section{Putting on}

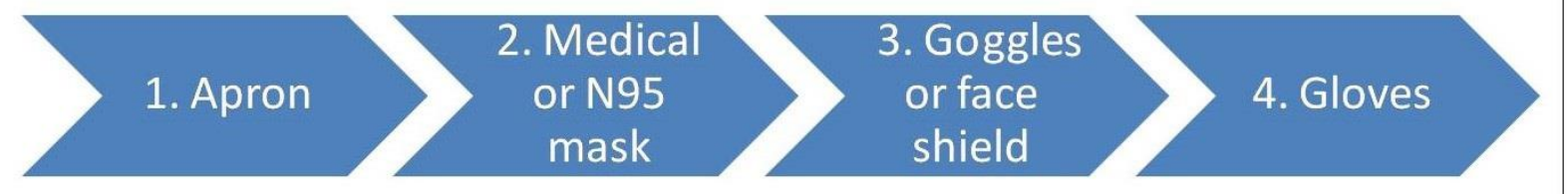

-Hands will not touch the face, the surfaces touched by the hands will be minimized.

\section{Removing}

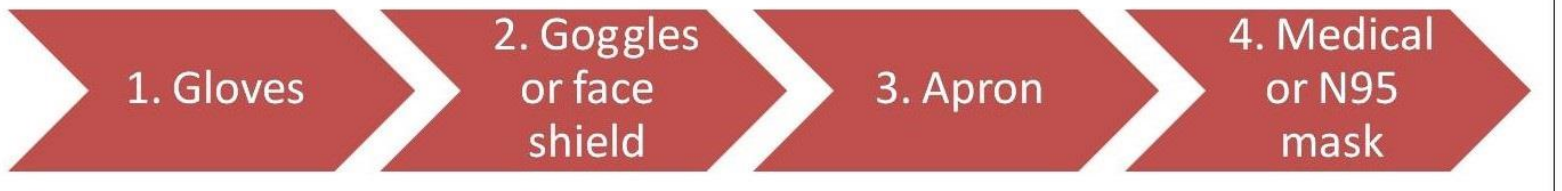

- At the end hands will be cleaned with water and soap or disinfectants. Hands will not touch the outer surfaces of the clothing. If there is contact with the contaminated surface, the hands should be cleaned between the steps.

Figure 5. The order of putting on and removing personal protective equipment

\section{Investigating the Field, Filiation}

Field investigation or named as filiation studies is to work on determining the source and factor and take protection and control measures, to safely isolate and follow the transmission. ${ }^{55}$ In our country healthy individuals, or suspected ones and diagnosed patients are all evaluated in detail. After the possible or definitive case is detected in the hospital, the case is processed in the Public Health Management System. The District Health Directorate's field team gets in contact with the patient and case is evaluated. From close relatives or households or co-workers of the patient samples of nasopharyngeal swabs are taken if they have any suspicious symptoms or sign. Chloroquine treatment is given to the individuals who are positive, and those who have mild disease. They are encouraged to comply with the isolation rules and their information is shared to their own family practitioner to be followed up properly. The cases are contacted and informed by family physicians over 
the phone for 14 days daily. Patients whose symptoms are gradually increasing are referred to the 2 nd or 3 rd level health institutions accompanied by 112 Emergency Service, thus ensuring that people who are sick are treated early. ${ }^{20}$ These all investigation studies aim to reduce hospitalizations and deaths due to COVID-19 infectious disease.

\section{Approach to the Patient in Isolation}

During the pandemic, each individual is already asked to isolate himself even without any sign or suspect of infection. Besides, patients diagnosed with COVID-19 or patients who are considered to be at high risk as a result of examinations, tests and imaging, but do not need inpatient treatment should be quarantined at home. These individuals also need to isolate themselves from individuals around the work or home. Individuals contacted with a patient diagnosed with COVID-19 and individuals who have someone diagnosed with COVID19 at home, are also isolated. After the field investigation and filiation studies completed, patients or high risk individuals are phone called by family physicians and their clinical status is monitored continuously for at least 14 days. $^{20}$

When the patient is called, physicians ask about patient's general clinical situation and how he feels compared to yesterday. In particular, cough, shortness of breath and fever are important symptoms to be followed. All these findings and the day of contact are noted on the family medicine information software. When any of the symptoms of cough, fever and shortness of breath develop, the patient should be directed to the emergency room with the mask on. In addition to three major complaints, it is necessary to evaluate other upper respiratory tract infection symptoms or any other suspicious complaints and refer patient to district health directorates, COVID-19 pandemic hospitals or other planned healthcare centers. However, this referral conditions may change with the availability of facilities, occupancy rates of inpatient clinics and the state of the pandemic in the region. ${ }^{20,56}$

Patients can be followed up by communicating with the patient remotely, through the health equipment they have at home. They can be explained how to use the thermometer or the sphygmomanometer if available. Counting the number of breaths can be explained. Although it is not yet valid and validated in our country, at that difficult times, telemedicine applications, video conversations with the patient, monitoring of some vital signs with smart devices can be brought to the agenda. Other complaints of patients can be met in these ways. In addition, family physicians by informing to its entire population, can enable individuals with cough, fever and shortness of breath to contact with the phone before coming to the family health center and so they can be referred directly. ${ }^{57}$ 


\section{References}

1. World Health Organisation Department of Communicable Disease Surveillance and Response. WHO guidelines for the global surveillance of severe acute respiratory syndrome ( SARS ) 2004. [Internet]. https://www.who.int/csr/resources/publications/WHO_CDS_CSR_ARO_2004_1.pdf (Access Date: 04.04.2020)

2. Sampathkumar, Priya Temesgen Z, Smith TF, Thompson RL. SARS: Epidemiology, Clinical Presentation, Management, and Infection Control Measures. Mayo Clin Proc 2003;78:882-90.

3. World Health Organisation. Middle East respiratory syndrome coronavirus (MERS-CoV) 2019 [Internet]. https://www.who.int/en/news-room/fact-sheets/detail/middle-east-respiratory-syndrome-coronavirus(mers-cov) (Access Date: 06.04.2020)

4. Huang C, Wang Y, Li X, Ren L, Zhao J, Hu Y, et al. Clinical features of patients infected with 2019 novel coronavirus in Wuhan, China. Lancet 2020;395:497-506.

5. World Health Organisation. Laboratory testing for coronavirus disease ( COVID-19) in suspected human cases. 2020. [Internet]. https://apps.who.int/iris/bitstream/handle/10665/331501/WHO-COVID-19laboratory-2020.5-eng.pdf (Access Date: 31.03.2020)

6. Chan JFW, Yuan S, Kok KH, To KKW, Chu H, Yang J, et al. A familial cluster of pneumonia associated with the 2019 novel coronavirus indicating person-to-person transmission: a study of a family cluster. Lancet 2020;395:514-23.

7. Lu R, Zhao X, Li J, Niu P, Yang B, Wu H, et al. Genomic characterisation and epidemiology of 2019 novel coronavirus: implications for virus origins and receptor binding. Lancet 2020;395:565-74.

8. Van Doremalen N, Bushmaker T, Morris DH, Holbrook MG, Gamble A, Williamson BN, et al. Aerosol and Surface Stability of SARS-CoV-2 as Compared with SARS-CoV-1. N Engl J Med 2020;382(1):1564-7.

9. Aylward, Bruce (WHO); Liang W (PRC). Report of the WHO-China Joint Mission on Coronavirus Disease 2019 (COVID-19) 2020. [Internet]. http://www.who.int/docs/default-source/coronaviruse/who-chinajoint-mission-on-covid-19-final-report.pdf (Access Date: 06.04.2020) 
10. Burke RM, Midgley CM, Dratch A, Fenstersheib M, Haupt T, Holshue M, et al. Active Monitoring of Persons Exposed to Patients with Confirmed COVID-19 - United States, January-February 2020. Morb Mortal Wkly Rep 2020;69(9):245-6.

11. Wei WE, Li Z, Chiew CJ, Yong SE, Toh MP, Lee VJ. Presymptomatic Transmission of SARS-CoV-2. Morb Mortal Wkly Rep 2020;69(14):411-5.

12. Wang C, Horby PW, Hayden FG, Gao GF. A novel coronavirus outbreak of global health concern. Lancet 2020;395(10223):470-3.

13. Chen N, Zhou M, Dong X, Qu J, Gong F, Han Y, et al. Epidemiological and clinical characteristics of 99 cases of 2019 novel coronavirus pneumonia in Wuhan, China: a descriptive study. Lancet 2020;395:507-13.

14. Wang D, Hu B, Hu C, Zhu F, Liu X, Zhang J, et al. Clinical Characteristics of 138 Hospitalized Patients With 2019 Novel Coronavirus-Infected Pneumonia in Wuhan, China. J Am Med Assoc 2020;323(11):1061-9.

15. Tian S, Hu N, Lou J, Chen K, Kang X, Xiang Z, et al. Characteristics of COVID-19 infection in Beijing. J Infect 2020;80(4):401-6. (doi:10.1016/j.jinf)

16. Guan W, Ni Z, Hu Y, Liang W, Ou C, He J, et al. Clinical Characteristics of Coronavirus Disease 2019 in China. New Engl J Med J Med Orig 2020;1-13. (doi:10.1056/NEJMoa2002032)

17. Cao Y, Liu X, Xiong L, Cai K. Imaging and Clinical Features of Patients With 2019 Novel Coronavirus SARS-CoV-2: A systematic review and meta-analysis. J Med Virol 2020;(March):1-11.

18. Wang W, Xu Y, Gao R, Lu R, Han K, Wu G, et al. Detection of SARS-CoV-2 in Different Types of Clinical Specimens. Journal of the American Medical Association. 2020;19-20. (doi:10.1001/jama.2020.3786)

19. Zhao J, Yuan Q, Wang H, Liu W, Liao X, Su Y, et al. Antibody responses to SARS-CoV-2 in patients of novel coronavirus disease 2019. Clin Infect Dis 2020;March. (doi:10.1093/cid/ciaa344)

20. T.C. Sağlık Bakanlığı Halk Sağlığı Genel Müdürlüğü. COVID-19 Rehberi 2020. [Internet]. https://covid19bilgi.saglik.gov.tr/depo/rehberler/COVID-19_Rehberi.pdf (Access Date: 18.04.2020)

21. Lauer SA, Grantz KH, Bi Q, Jones FK, Zheng Q, Meredith HR, et al. The Incubation Period of Coronavirus Disease 2019 (COVID-19) From Publicly Reported Confirmed Cases: Estimation and Application. Ann Intern Med 2020. (doi:10.7326/M20-0504) 
22. Yoon SH, Lee KH, Kim JY, Lee YK, Ko H, Kim KH, et al. Chest radiographic and ct findings of the 2019 novel coronavirus disease (Covid-19): Analysis of nine patients treated in korea. Korean J Radiol 2020;21(4):498-504.

23. Lee EYP, Ng MY, Khong PL. COVID-19 pneumonia: what has CT taught us? Lancet Infect Dis 2020;20(4). 384-5.

24. Ai T, Yang Z, Hou H, Zhan C, Chen C, Lv W, et al. Correlation of Chest CT and RT-PCR Testing in Coronavirus Disease 2019 (COVID-19) in China: A Report of 1014 Cases. RSNA - Radiol 2020 (doi:10.1148/radiol.2020200642)

25. Touret F, de Lamballerie X. Of chloroquine and COVID-19. Antiviral Res 2020;177:104762. (doi:10.1016/j.antiviral.2020.104762.)

26. Ahn D, Shin H, Kim M-H, Lee S, Kim H-S, Myoung J, et al. Current Status of Epidemiology, Diagnosis, Therapeutics, and Vaccines for Novel Coronavirus Disease 2019 (COVID-19). J Microbiol Biotechnol $2020 ; 30(3): 313-24$.

27. Wang M, Cao R, Zhang L, Yang X, Liu J, Xu M, et al. Remdesivir and chloroquine effectively inhibit the recently emerged novel coronavirus (2019-nCoV) in vitro. Cell Res 2020;30(3):269-71.

28. Gao J, Tian Z, Yang X. Breakthrough: Chloroquine phosphate has shown apparent efficacy in treatment of COVID-19 associated pneumonia in clinical studies. Biosci Trends 2020;14(1):1-2.

29. Yao X, Ye F, Zhang M, Cui C, Huang B, Niu P, et al. In Vitro Antiviral Activity and Projection of Optimized Dosing Design of Hydroxychloroquine for the Treatment of Severe Acute Respiratory Syndrome Coronavirus 2 (SARS-CoV-2). Clin Infect Dis 2020. (doi:10.1093/cid/ciaa237)

30. Chatre C, Roubille F, Vernhet H, Jorgensen C, Pers YM. Cardiac Complications Attributed to Chloroquine and Hydroxychloroquine: A Systematic Review of the Literature. Drug Safety 2018;41:919-31.

31. Aktoz M, Altay H, Aslanger E, Atalar E, Aytekin V, Baykan AO, et al. Consensus Report from Turkish Society of Cardiology: COVID-19 and Cardiovascular Diseases. What cardiologists should know. Arch Turkish Soc Cardiol 2020;48(0):1-48. (doi:10.5543/tkda.2020.97198)

32. Chen L, Xiong J, Bao L, Shi Y. Convalescent plasma as a potential therapy for COVID-19. Lancet 2020;20:398-9. 
33. Zhang J, Ma X, Yu F, Liu J, Zou F, Pan T, et al. Teicoplanin potently blocks the cell entry of 2019-nCoV. bioRxiv 2020. (doi:10.1101/2020.02.05.935387)

34. Zhou F, Yu T, Du R, Fan G, Liu Y, Liu Z, et al. Clinical course and risk factors for mortality of adult inpatients with COVID-19 in Wuhan, China: a retrospective cohort study. Lancet 2020;395(10229):1054-62.

35. Miller A, Reandelar MJ, Fasciglione K, Roumenova V, Li Y, Otazu GH. Correlation between universal BCG vaccination policy and reduced morbidity and mortality for COVID-19: an epidemiological study. J Chem Inf Model 2012;53(9):1689-99.

36. Chen D, Xu W, Lei Z, Huang Z, Liu J, Gao Z, et al. Recurrence of positive SARS-CoV-2 RNA in COVID-19: A case report. Int J Infect Dis 2020;93:297-9.

37. Zhou D, Dai S-M, Tong Q. COVID-19: a recommendation to examine the effect of hydroxychloroquine in preventing infection and progression. J Antimicrob Chemother 2020;(February):47.(doi:10.1093/jac/dkaa114/5810487)

38. Agrawal S, Goel AD, Gupta N. Emerging prophylaxis strategies against COVID-19. Monaldi Arch Chest Dis 2020;90(1):169-72.

39. Indian Council of Medical Research. Advisory on the use of Hydroxychloroquin as prophylaxis for SARS CoV2 infection. 2020. [Internet]. https://www.mohfw.gov.in/pdf/AdvisoryontheuseofHydroxychloroquinasprophylaxisforSARSCoV2infe ction.pdf (Access Date: 24.03.2020)

40. World Health Organisation. Coronavirus disease (COVID-19) advice for the public: Myth busters. 2020. [Internet]. https://www.who.int/emergencies/diseases/novel-coronavirus-2019/advice-forpublic/myth-busters (Access Date: 01.04.2020)

41. World Health Organisation. Coronavirus disease (COVID-19) advice for the public: When and how to use masks. 2020. [Internet]. https://www.who.int/emergencies/diseases/novel-coronavirus-2019/advicefor-public/when-and-how-to-use-masks (Access Date: 08.04.2020)

42. T.C. İçişleri Bakanlığı. Şehir Giriş/Çıkış Tebirleri ve Yaş Sınırlaması Genelgesi Turkiye; 2020. [Internet]. Available from: https://www.icisleri.gov.tr/sehir-giriscikis-tebirleri-ve-yas-sinirlamasi (Access Date: 22.04.2020) 
43. Klompas M, Morris CA, Sinclair J, Pearson M, Shenoy ES. Universal Masking in Hospitals in the Covid-19 Era. N Engl J Med 2020;382:1476-78. (doi:10.1056/NEJMp2006372)

44. American Academy of Family Physicians. COVID-19: Guidance for Family Physicians on Preventive and Non-Urgent Care. 2020.

45. T.C. Sağlık Bakanlığı Sağlık Hizmetleri Genel Müdürlüğü. Poliklinik ve Sağlık Raporları Hakkında Alınacak Tedbirler Turkiye; 2020. [Internet]. https://dosyamerkez.saglik.gov.tr/Eklenti/36990,poliklinik-ve-saglikustyazi961f936a-5827-4b02-b5fed0d7c5ca81c1pdf.pdf?0\&_tag1=D16155C87DEE76A7E26083D1E8C0AE4754D1502D (Access Date: 22.04.2020)

46. British Columbia Centre for Disease Control. Environmental Cleaning and Disinfectants for Clinic Settings.; 2020. [Internet]. http://www.bccdc.ca/Health-Professionals-Site/Documents/COVID19_MOH_BCCDC_EnvironmentalCleaning.pdf (Access Date: 24.04.2020)

47. Health Protection Scotland. Novel coronavirus (COVID-19) Guidance for primary care. 2020. [Internet]. https://assets.publishing.service.gov.uk/government/uploads/system/uploads/attachment_data/file/8 81489/COVID-19_Infection_prevention_and_control_guidance_complete.pdf (Access Date: 26.04.2020)

48. European Centre for Disease Prevention and Control. Safe use of personal protective equipment in the treatment of infectious diseases of high consequence: A tutorial for trainers in healthcare settings. 2014. [Internet]. https://www.ecdc.europa.eu/sites/default/files/media/en/publications/Publications/safeuse-of-ppe.pdf (Access Date: 18.04.2020)

49. Centers for Disease Control and Prevention. Jong, de F. Infographic- Understanding the Diffirence, Surgical Mask, N95 Respirator 2018. [Internet]. https://www.cdc.gov/niosh/npptl/pdfs/UnderstandDifferenceInfographic-508.pdf (Access Date: 10.04.2020)

50. Stanford Medicine. Price A, Chu L. What are good ways to address the shortage of face masks by anesthesiologists ? 2020. [Internet]. https://stanfordmedicine.app.box.com/v/covid19-PPE-1-1 (Access Date: 03.04.2020)

51. Tsai P. Information and FAQs on the Performance, Protection, and Sterilization of Face Mask Materials. 2020. [Internet]. Available from: https://utrf.tennessee.edu/information-faqs-performance-protectionsterilization-of-face-mask-materials/ (Access Date: 04.04.2020) 
52. Türk Tabipler Birliği. Sağlık çalışanında Covid-19 tanısı iş kazası veya meslek hastalığıdır [Internet]. https://www.ttb.org.tr/haber_goster.php?Guid=92238894-726a-11ea-b12d-d839943d748d (Access Date: 10.04 .2020 )

53. World Health Organisation. Rational use of personal protective equipment for coronavirus disease 2019 ( COVID-19). 2020. [Internet]. https://www.who.int/publications-detail/rational-use-of-personalprotective-equipment-for-coronavirus-disease-(covid-19)-and-considerations-during-severe-shortages (Access Date: 14.04.2020)

54. Goodwin Veenema T. Sequence for Putting on Personal Protective Equipment. In: Disaster Nursing and Emergency Preparedness 2018. p. 682-4. [Internet]. https://www.cdc.gov/hai/pdfs/ppe/ppesequence.pdf (Access Date: 10.04.2020)

55. T.C. Sağlık Bakanlığı Halk Sağlığı Genel Müdürlüğü. Bulaşıcı Hastalıklarla Mücadele Rehberi Turkiye; 2018. [Internet]. https://hsgm.saglik.gov.tr/depo/mevzuat/genelge/Bulasici_Hastaliklar_ile_Mucadele_Rehberi_Ustyazi.p df (Access Date: 22.04.2020)

56. European Center for Disease Prevention and Control. Coronavirus disease 2019 (COVID-19) pandemic: increased transmission in the EU/EEA and the UK - seventh update. 2020; [Internet]. https://www.ecdc.europa.eu/sites/default/files/documents/RRA-seventh-update-Outbreak-ofcoronavirus-disease-COVID-19.pdf (Access Date: 28.03.2020)

57. Ontorio College of Family Physicians. Tips for family doctors. 2020 [Internet]. https://www.ontariofamilyphysicians.ca/tools-resources/timely-trending/novel-coronavirus-2019ncov/novel-coronavirus:-tips-for-family-doctors (Access Date: 02.04.2020) 